NASA

Technical Memorandum 104336

AIAA-91-1907
AVSCOM

Technical Report 91-C-007

\title{
Evaluation of Advanced Lubricants for Aircraft Applications Using Gear Surface Fatigue Tests
}

Dennis P. Townsend

Lewis Research Center

Cleveland, Ohio

and

John Shimski

Naval Air Propulsion Center

Trenton, New Jersey

Prepared for the

27th Joint Propulsion Conference

cosponsored by AIAA, SAE, ASEE and ASME

Sacramento, California, June 24-26, 1991 
EVALUATION OF ADVANCED LUBRICANTS FOR AIRCRAFT APPLICATIONS

USING GEAR SURFACE FATIGUE TESTS

Dennis P. Townsend

National Aeronautics and Space Administration

Lewis Research Center

Cleveland, Ohio 44135

and

John Shimski

Naval Air Propulsion Center

Trenton, New Jersey 08628

\section{Abstract}

Surface pitting fatigue life tests were conducted with five lubricants, using spur gears made from a single lot of consumable-electrode vacuum melted (CVM) AISI 9310 steel. The gears were case carburized and hardened to a Rockwell $\mathrm{C}-60$ and $\mathrm{fin}-$ ish ground. The gear pitch diameter was $8.89 \mathrm{~cm}$ ( 3.5 in.). The lot of gears was divided into five groups, each of which was tested with a different lubricant. The test lubricants can be classified as synthetic polyol-esters with various viscosities and additive packages. Test conditions included a bulk gear temperature of $350 \mathrm{~K}\left(170^{\circ} \mathrm{F}\right)$, a maximum Hertz stress of $1.71 \mathrm{GPa}(248 \mathrm{ksi})$ at the pitch line, and a speed of 10000 RPM. The following results were obtained. The lubricant with a viscosity that provided a specific film thickness greater than one and with an additive package produced far greater gear surface fatigue lives than lubricants with a viscosity that provided specific film thickness less than one. A low viscosity lubricant with an additive package produced gear surface fatigue lives equivalent to a similar base stock lubricant with 30 percent higher viscosity but without an additive package. Lubricants with the same viscosity and similar additive packages gave equivalent gear surface fatigue lives.

\section{Introduction}

The transmission for helicopters, turboprop, and geared fan aircraft are required to have high reliability and provide several thousand hours of operation. In addition, they should be lightweight and have very high efficiency to minimize operating costs for the aircraft.

Most of the aircraft operating today are using turbine engine lubricants to lubricate the transmissions. While these lubricants provide good lubrication, thermal stability, and low operation temperatures for the turbine engines they are less than optimum for good reliability and long life for transmissions.

Tests with rolling element bearings ${ }^{1,2}$ have shown that bearing life is affected by the lubricant elastohydrodynamic (EHD) film thickness. When the EHD film thickness divided by the composite surface roughness $h / \sigma$ is less than 1 the life of rolling element components is considerably reduced.
In gearing the effect of operating with an $\mathrm{h} / \sigma$ of less than one is more pronounced than it is with bearings. This is because of the higher sliding conditions encountered with gearing which causes increased surface heating and higher friction coefficients resulting in reduced surface fatigue $l i \mathrm{fe}^{3}$ and increased wear or scoring risk.

Gear tests conducted with several lubricant and additives ${ }^{4}$ have shown that the gear surface fatigue life can be improved somewhat with the right choice of additives. Lubricants with the same viscosity but with different additives produced gear surface fatigue lives with a difference of five to one. The above mentioned tests indicted the necessity of having the proper additive in the lubricant but did not determine what affect different lubricant viscosity of the same base stock would have on gear fatigue life.

The effect of the EHD film thickness on scoring and wear under various slide to roll ratios was determined in Ref. 5 using rolling sliding cylinders. When the specific film thickness or $\mathrm{h} / \sigma$ was less than or equal to 0.3 the rolling sliding cylinders experienced wear and scoring, and indicated an increase in friction coefficient and temperature. These tests also showed an increase in scoring load capacity with EP additives in the lubricant.

Lubricant suppliers have recognized the need for supplying better lubricants for the modern gearboxes that operate at increased power density. Tests have shown that lubricants with the proper base stock, viscosity, and additives can improve the load capacity and efficiency of transmissions.

The research work reported herein was undertaken to investigate the effects of lubricants with the same base stock bu with different viscosities on the surface fatigue life of AISI 9310 spur gears. The objectives were: (1) to investigate the effect of five different lubricants on the surface fatigue life of hardened steel spur gears, (2) to compare the gear fatigue life with four of the five lubricants to a reference lubricant, and (3) to determine the effects of lubricant viscosity on the surface fatigue life of spur gears.

To accomplish these objectives, one lot of spur gears was manufactured from a single heat of (CVM) AISI 9310 material. The test gears were case 
carburized, hardened and ground to the same specifications. The gear pitch diameter was $8.89 \mathrm{~cm}$ ( 3.5 in.). The lot of gears was divided into five groups, each of which was tested with a different lubricant. The test lubricants can be classified as synthetic polyol-ester with different viscosity properties. Test conditions include a bulk gear temperature of $350 \mathrm{~K}\left(170^{\circ} \mathrm{F}\right)$, a maximum Hertz stress of $1.71 \mathrm{GPa}(248 \mathrm{ksi}$ ) at the pitch line and a speed of 10000 RPM.

\section{Gear Test Apparatus}

The gear fatigue tests were performed in the NASA Lewis Research Center's gear test apparatus. The test rig is shown in Fig. 1 and described in Ref. 7. This test rig uses the four-square principle of applying the test gear load so that the input drive only needs to overcome the frictional losses in the system.

A schematic of the test rig is shown in Fig. (b). Oil pressure and leakage flow are supplied to the load vanes through a shaft seal. As the oil pressure is increased on the load vanes inside the slave gear, torque is applied to the shaft. This torque is transmitted through the test gears back to the slave gear where an equal but opposite torque is maintained by the oil pressure. This torque on the test gears, which depends on the hydraulic pressure applied to the load vanes, loads the gear teeth to the desired stress level. The two identical test gears can be started under no load, and the load can be applied gradually, without changing the running track on the gear teeth.

Separate lubrication systems are provided for the test gears and the main gearbox. The two lubricant systems are separated at the gearbox shafts by pressurized labyrinth seals, using nitrogen as the seal gas. The test gear lubricant is filtered through a $5-\mu \mathrm{m}$ nominal fiberglass filter. The test lubricant can be heated electrically with an immersion heater. The skin temperature of the heater is controlled to prevent overheating the test lubricant.

A vibration transducer mounted on the gearbox is used to automatically shut off the test rig when a gear-surface fatigue spall occurs. The gearbox is also automatically shut of $f$ if there is a loss of oil flow to either the main gearbox or the test gears, if the test gear oil overheats, or if there is a loss of seal gas pressurization.

The belt-driven test rig can be operated at several fixed speeds by changing pulleys. The operating speed for the tests reported herein was $10000 \mathrm{rpm}$.

\section{Test Gears}

Dimensions for the test gears are given in Table 3. All gears have a nominal surface finish on the tooth face of $0.406 \mu \mathrm{m}$ (16 $\mu \mathrm{in})$, rms, and a standard $20^{\circ}$ involute profile with tip relief. Tip relief was $0.0013 \mathrm{~cm}(0.0005 \mathrm{in.})$, starting at the highest point of single tooth contact.

The test gears were manufactured from consumable-electrode vacuum-melted (CVM) AISI 9310 steel from the same heat of material. The nominal chemical composition of the material is given in Table 1. All sets of gears were case carburized and heat treated in accordance with the heat treatment schedule of Table 2 . Figure 2 is a photomicrograph of an etched and polished gear tooth showing the case and core microstructure of the AISI 9310 material. This material has a case hardness of Rockwell C60 and a case depth of $0.97 \mathrm{~mm}$ $(0.038 \mathrm{in.})$. The nominal core hardness was Rockwell C38.

\section{Test Lubricants}

Five lubricants were selected for surface fatigue endurance tests with the CVM AISI 9310 steel gear test specimens. Lubricant $A$ is an unformulated base stock lubricant with no lubricant additives and with a viscosity in between the MIL-L-7808J and MIL-L-23699 specifications and does not meet either specification. Lubricant $A$ was used as the reference lubricant to compare the results with the other lubricants. Lubricant $B$ is a 5 cSt lubricant meeting the MIL-L-23699 specification. Two batches of this lubricant were used because of an error in determining how much would be required to conduct the testing. However, both batches were nearly identical in every respect. Lubricant $C$ meets the MIL-L-7808J specification and had the lowest viscosity of all the lubricants tested. Lubricant $D$ was a lubricant developed for helicopter gearboxes under the specification DOD-L-85734 and was also a 5 cSt lubricant. Lubricant $\mathrm{E}$ was a 7.5 cSt lubricant meeting a special development specification DERD-2487. All five of the lubricants could be classified as synthetic polyol-ester base stock lubricants.

The pitch line elastohydrodynamic (EHD) film thickness was calculated by the method of Refs. 8 and 9. It was assumed for this film thickness calculation that the gear surface temperature at the pitch line was equal to the oil temperature measured at the outlet of the gearbox and that the oil temperature entering the EHD contact zone was equal to this gear temperature even though the temperature of the oil jet lubricating the gear was much lower. It is most probable that the gear surface temperature was higher than the oil outlet temperature based on temperature measurements made in Ref. 4.

The computed EHD film thicknesses are given in Table 4 as are initial $\Lambda$ ratios (film thickness divided by composite surface roughness $(h / \sigma)$ ) at the $1.71 \mathrm{GPa}(248 \mathrm{ksi})$ pitch line maximum Hertz stress.

\section{Test Procedure}

The test gears were cleaned to remove a preservative, and assembled on the test rig. The test gears were run in an offset condition with a $0.305 \mathrm{~cm}(0.120 \mathrm{in.})$ tooth-surface overlap to give a load surface on the gear face of $0.28 \mathrm{~cm}$ $(0.110 \mathrm{in.})$, thereby allowing for the edge radius of the gear teeth. Therefore if both faces of the gears were tested, four fatigue tests could be run for each pair of gears. All tests were run-in at a load of $1225 \mathrm{~N} / \mathrm{cm}(700 \mathrm{lb} / \mathrm{in}$.) for $\mathrm{i} \mathrm{hr}$. The load was then increased to $5784 \mathrm{~N} / \mathrm{cm}$ (3305 lb/in.), which gives a $1.71 \mathrm{GPa}$ ( 248000 psi) maximum Hertz stress at the tooth pitch line. At the pitch-line 
load the tooth bending stress was $0.21 \mathrm{GPa}$ ( 30000 psi) if plain bending is assumed. However, because of the offset load, additional stress is imposed on the tooth bending stress. Combining the bending and torsional moments gives a maximum stress of $0.26 \mathrm{GPa}$ ( $37000 \mathrm{psi}$ ). This bending stress does not include the effects of tip relief which would also increase the bending stress. In general, 20 tests were run for each lubricant.

Operating the test gears at $10000 \mathrm{rpm}$ gave a pitch-line velocity of $46.55 \mathrm{~m} / \mathrm{sec}$ (9163 ft/min). Lubricant was supplied to the inlet mesh at $800 \mathrm{~cm}^{3} / \mathrm{min}(0.21 \mathrm{gal} / \mathrm{min})$ at $320 \pm 6 \mathrm{~K}\left(116 \pm 10^{\circ} \mathrm{F}\right)$. The lubricant outlet temperature was nearly constant at $350 \pm 3 \mathrm{~K}\left(170 \pm{ }^{\circ} \mathrm{F}\right)$. The tests ran continuously ( $24 \mathrm{hr} / \mathrm{day}$ ) until they were automatically shut down by the vibration detection transducer, located on the gearbox adjacent to the test gears. The lubricant circulated through a $5-\mu \mathrm{m}$ fiberglas!3 filter to remove wear particles. After each test the lubricant and filter element were discarded. Inlet and outlet oil temperatures were continuously recorded on a stripchart recorder. After each set of lubricant tests the system was partially disassembled, flushed with trichloroethane and then with alcohol, dried, and reassembled before a new lubricant was used in the system.

\section{Results and Discussion}

\section{Gear Life}

The surface pitting fatigue lives of the AISI 9310 gears run with all five lubricants are shown in Fig. 3 and Table 5. These data are shown on Weibull coordinates and were analyzed by the method of Ref. 10. The life shown is the life of gear pairs in millions of stress cycles or millions of revolutions. A failure is defined as one or more spalls covering more than 50 percent of the width of the Hertzian contact. Typical fatigue spalls for each lubricant along with cross sections of the fatigue spalls are shown in Figs. 4 to 8.

Lubricant A (Fig. 3(a)) is the reference oil for these lubricant tests. The 10- and 50-percent system (two gears) lives (the life at 90- and 50-percent probability of survival) were $5.1 \mathrm{mil-}$ lion and 20.4 million revolutions or stress cycles, respectively. The failure index was 30 out of 30 which is the number of failures out of the number of tests conducted. A typical fatigue spall with lubricant $A$ is shown in Fig. 4.

The surface pitting fatigue lives of the AISI 9310 gears run with lubricant $B$ are shown in Fig. 3(b). A typical fatigue spall for lubricant B is shown in Fig. 5. Lubricant $B$ is a 5 cSt lubricant meeting the MIL-L-23699 specification. The 10 - and 50-percent system lives of the gears run with lubricant $B$ were 12.1 million and 76 million revolutions or stress cycles, respectively. The failure index for this lubricant was 20 out of 20 . These data indicate that the fatigue life of 9310 gears run with lubricant B is approximately 2.4 times that for lubricant $A$. The confidence number for the life difference between lubricant $B$ and lubricant $A$ was 84 percent which indicates that the difference is statistically significant. The confidence number indicates the percentage of time the order of the test results will be the same. For a confidence number of 84 percent, 84 out of 100 times the test is repeated the gear life with lubricant B will be higher than lubricant A. Experience has shown that a confidence number of 80 percent or greater would indicate a meaningful life difference.

The life difference between lubricant $A$ and lubricant $B$ of over two to one would no be expected based on the small difference in lubricant viscosity and specific film thickness. However, when it is considered that lubricant $A$ does not have an additive package that would include an EP additive, then the life difference is more in line with expected results based on the test conducted in Ref. 11.

The surface pitting fatigue lives obtained with lubricant $\mathrm{C}$ are shown in Fig. 3(e). Lubricant $C$ is a 3 Cst lubricant meeting the MIL-L-7808J specification. A typical fatigue spall for lubricant $\mathrm{C}$ is shown in Fig. 6. The 10- and 50-percent systems lives of the 9310 gears run with lubricant $C$ were 5.67 million and 20.7 million revolutions or stress cycle, respectively. The failure index for this lubricant was 20 out of 20 . These data indicate that the fatigue life of 9310 gears run with lubricant $C$ was nearly equivalent to that with lubricant $A$. The confidence number for the life difference between lubricant $C$ and lubricant $A$ was 55 percent which indicates that the difference is not statistically significant. The gear life with lubricant $C$ would not be expected to equal the gear life with lubricant $A$ based on the lubricant viscosity alone. However, lubricant $\mathrm{C}$ is a formulation which contained some EP additives while lubricant A is a base stock lubricant without EP additives. Since the tests with both lubricant $A$ and $C$ were run with specific film thickness in the mixed or boundary regime then the EP additives in lubricant $C$ would improve the gear life over that for lubricant $A$. This points out the need for EP additives in lubricants used for gears operating with specific film thickness less than one as demonstrated in other tests.

The gear surface pitting fatigue lives obtained with lubricant $D$ are shown in Fig. 3 (d). The 10- and 50-percent system lives of the 9310 gears tested with lubricant $D$ were 11.75 million and $50.8 \mathrm{million}$ revolutions or stress $\mathrm{c}_{y} \mathrm{cles}$, respectively. The failure index for this lubricant was 17 out of 20 and there were three suspended tests that completed 300 million stress cycles without failure. A typical fatigue spall for lubricant D is shown in Fig. 7. The life for lubricant $D$ was 2.3 times that for the reference lubricant $A$ and was nearly identical to the life for lubricant B. Lubricant $D$ has nearly the same viscosity as lubricant $B$ and a similar additive package that includes an EP additive. It is, therefore, expected that the two lubricants $B$ and $D$ should have nearly identical lives. Lubricant A, on the other hand, has only slightly less viscosity than lubricant $D$ but does not have an additive package or EP additive which is the most probable reason for the shorter life of lubricant $A$. The confidence number for the life difference between lubricant $D$ and $A$ was 83 percent which means that the life difference is statistically significant.

The gear surface pitting fatigue lives obtained with lubricant $E$ are plotted on Weibull coordinates shown in Fig. $3(e)$. A typical fatigue 
spall for lubricant $\mathrm{E}$ is shown in Fig. 8. The 10and 50-percent system lives of the 9310 spur gears tested with lubricant $\mathrm{E}$ were 46.5 million and 152 million stress cycles or revolutions, respectively. The failure index for lubricant $\mathrm{E}$ was 15 out of 19 with four tests that were suspended after $500 \mathrm{hr}$ or 300 million stress cycles without failure. The confidence number for the life difference between lubricant $\mathrm{E}$ and $\mathrm{A}$ was 99 percent which shows that the life difference is statistically significant.

These life results are summarized in Fig. 3 and Table 5. The life of lubricant $E$ was more than nine times that for lubricant $A$ and nearly four times that for lubricant $B$ and $D$. Lubricant $E$ is a 7 cSt lubricant and had a calculated specific film thickness of 1.15. It was, therefore, expected that lubricant $\mathrm{E}$ would produce longer fatigue life than the other less viscous lubricants. However, it could not be analytically determined just how much improvement in surface fatigue could be obtained with this higher viscosity lubricant. The surface fatigue testing was, therefore, necessary to determine gear life with these lubricants. The test results are very conclusive in showing that when gears are operated with lubricants that provide specific film thickness around one or greater, the surface fatigue will show large improvements over some of the turbine engine lubricants that provide lower EHD specific film thickness. The above results also point out the need to provide separate lubricants from the engine lubricants for power transmissions such as turboprop or turbofan reduction gearboxes and helicopter gearboxes to provide increased life and reliability of these systems.

\section{Lubricant Effects on Gear Life}

There are many cases where gears are lubricated with a low to moderate viscosity lubricant, providing a specific film thickness considerably less than one. In these cases, based on the results presented here and other lubricant tests with gears, several things could be done to provide better protection or increased gear life. The lubricant should have an additive that will provide a low friction boundary film on the surface to prevent metal contact and to reduce the traction forces. Good cooling should be provided so that the viscosity of the lubricant is not further reduced resulting in lower film thickness and reduced life. The surface finish of the gears should be as small as in practical to improve the specific film thickness, thereby increasing the fatigue life. If it is not practical or possible to accomplish the above mentioned conditions, then a more viscous lubricant should be specified. The result of not using conditions of lubrication that provide boundary film and good specific film thickness is a reduced life of the gear system.

\section{Summary}

Spur gear surface pitting fatigue life tests were conducted with five lubricants, using a single lot of consumable-electrode vacuum melted (CVM) AISI 9310 steel spur gears. The gears were case carburized and hardened to a Rockwell C-60 and finish ground. The gear pitch diameter was $8.89 \mathrm{~cm}$ ( $3.5 \mathrm{in.)}$. The lot of gears was divided into five groups, each of which was tested with a different lubricant. The test lubricants can be classified as synthetic polyol-esters with various viscosities and additive packages. Test conditions included a bulk gear temperature of $350 \mathrm{~K}\left(170^{\circ} \mathrm{F}\right)$, a maximum Hertz stress of $1.71 \mathrm{GPa}(248 \mathrm{ksi})$ at the pitch line, and a speed of 10000 RPM. The following were obtained:

1. The lubricant with a viscosity that provide a specific film thickness greater than one and with an additive package produced far greater gear surface fatigue lives than lubricants with a viscosity that provided specific film thickness less than one.

2. A low viscosity lubricant with an additive package produced gear surface fatigue lives equivalent to a similar base stock lubricant with 30 percent higher viscosity but without an additive package.

3. Lubricants with the same viscosity and similar additive packages gave equivalent gear surface fatigue lives.

\section{References}

1. Zaretsky, E.V., Anderson, W.J., and Parker, R.J: "Effect of Nine Lubricants on Rolling-Contact Fatigue Life," NASA TN D-1404, 1962 .

2. Zaretsky, E.V., Sibley, L.B., and Anderson, w.J.: "The Role of Elastohydrodynamic Lubrication in Rolling-Contact Fatique," Journal of Basic Engineering, Vol. 85, No. 3, Sept. 1963, pp. 439-450.

3. Smith, J.O. and Liu, C.K., "Stresses Due to Tangential and Normal Loads on an Elastic solid with Application to Some Contact Stress Problems. Journal of Applied Mechanics, Vol. 20, No. 2, June 1953, pp. 157-166.

4. Townsend, D. and Akin, L., "Analytical and Experimental Spur Gear Tooth Temperature as Affected by Operating Variables," Journal of Mechanical Design, Vol. 103, No. 1, Jan. 1981, pp. 219-226.

5. Fujita, K., Obata, F., and Yamaura, I. "Effects of Specific sliding and sliding Velocity on Load Carrying Capacity of Non-EP and EP Oils in Two Cylinder Test," proceedings International Symposium on Gearing and Power Transmission, Japan Society of Mechanical Engineers, Tokyo, Japan, 1981, Vol. I, pp. 329-334.

6. Breau, J.Y., Fukui, M., and Murphy, W.R., "New Developments in Industrial Gear Lubrication," proceedings International Symposium on Gearing and Power Transmission, Japan Society of Mechanical Engineers, Tokyo, Japan, 1981, Vol. I, pp. 351-356.

7. Townsend, D.P., Chevalier, J.L., and Zaretsky, E.V., Pitting Fatigue Characteristics of AISI M-50 and Super Nitrallogy Spur Gears," NASA TN D-7261, 1973.

8. Townsend, D.P., "The Application of Elastohydrodynamic Lubrication in Gear Tooth Contacts," NASA TM X-68142, 1972. 
9. Dowson, D. and Higginson, G.R., Elastohydrodynamic Lubrication. Pergamon Press, 1966, pp. 96, 221 .

10. Johnson, L.G., The Statistical Treatment of Fatigue Experiments. Elsevier, 1964.
11. Scibbe, H.W., Townsend, D.P., and Aron, P.R., "Effect of Lubricant Extreme-Pressure Additives on Surface Fatigue Life of AISI 9310 Spur Gears," NASA TP-2408, 1984.

TABLE 1. - NOMINAL CHEMICAL COMPOSITION OF AISI 9310 GEAR MATERIAL

\begin{tabular}{|c|c|c|c|c|c|c|c|c|}
\hline $\mathrm{C}$ & $\mathrm{Mn}$ & $\mathrm{Si}$ & $\mathrm{Ni}$ & $\mathrm{Cr}$ & Mo & $\mathrm{Cu}$ & $\mathrm{P}$ & S \\
\hline \multicolumn{8}{|c|}{ Composition, wt 8 } \\
\hline 0.10 & 0.63 & 0.27 & 3.22 & 1.21 & 0.12 & 0.13 & 0.005 & 0.005 \\
\hline
\end{tabular}

TABLE 2. - HEAT TREATMENT FOR AISI 9310

\begin{tabular}{|c|l|r|r|l|}
\hline \multirow{2}{*}{ Step } & \multicolumn{1}{|c|}{ Process } & \multicolumn{1}{c|}{ Temperature } & \multirow{2}{*}{$\begin{array}{c}\text { Time, } \\
\text { hr }\end{array}$} \\
\cline { 3 - 4 } & & $K$ & ${ }^{\prime} F$ & \\
\hline 1 & Preheat in air & ---- & ---- & ------ \\
2 & Carburize & 1172 & 1650 & 8 \\
3 & Air cool to room temperature & ---- & ---- & ----- \\
4 & Copper plate all over & ---- & ---- & ------ \\
5 & Reheat & 922 & 1200 & 2.5 \\
6 & Air cool to room temperature & ---- & ---- & ------ \\
7 & Austenitize & 1.117 & 1550 & 2.5 \\
8 & Oil quench & ---- & ---- & ----- \\
9 & Subzero cool & 180 & -120 & 3.5 \\
10 & Double temper & 450 & 350 & 2 each \\
11 & Finish grind & ---- & ---- & ----- \\
12 & Stress relive & 450 & 350 & 2 \\
\hline
\end{tabular}

TABLE 3. - SPUR GEAR DATA

[Gear tolerance per ASMA class 12.]

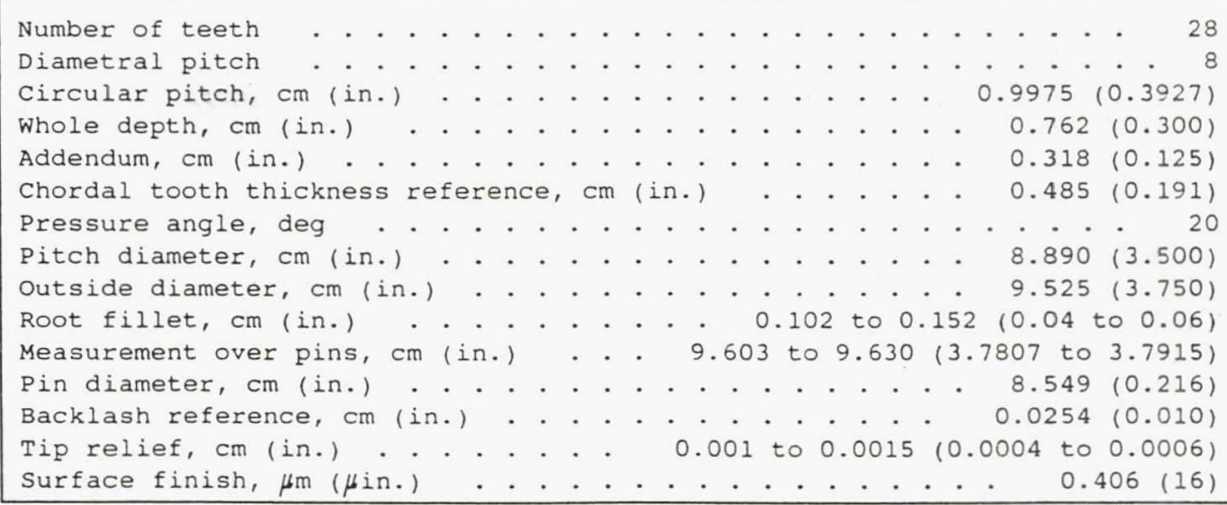


TABLE 4. - LUBRICANT PROPERTIES

\begin{tabular}{|c|c|c|c|c|c|c|}
\hline \multirow{3}{*}{$\begin{array}{l}\text { NASA identification } \\
\text { NAPC code number }\end{array}$} & \multicolumn{6}{|c|}{ Lubricant } \\
\hline & A & \multicolumn{2}{|c|}{ B } & \multirow{2}{*}{$\frac{C}{P E-3-L 1316}$} & \multirow{2}{*}{$\frac{D}{P E-5-L 1304}$} & \multirow{2}{*}{$\begin{array}{c}\mathrm{E} \\
\mathrm{PE}-7 \cdot 5- \\
\mathrm{L} 1310\end{array}$} \\
\hline & $P E-5-L 1274$ & $\mathrm{PE}-5-\mathrm{L} 1307$ & $\mathrm{PE}-5-\mathrm{L} 1553$ & & & \\
\hline $\begin{array}{l}\text { Kinematic viscosity at - } \\
311 \mathrm{~K}\left(100^{\circ} \mathrm{F}\right) \\
313 \mathrm{~K}\left(104^{\circ} \mathrm{F}\right) \\
372 \mathrm{~K}\left(210^{\circ} \mathrm{F}\right) \\
373 \mathrm{~K}\left(212^{\circ} \mathrm{F}\right)\end{array}$ & $\begin{array}{l}21.0 \\
----- \\
4.31 \\
------\end{array}$ & $\begin{array}{r}30.27 \\
----- \\
5.46 \\
-----\end{array}$ & $\begin{array}{r}29.11 \\
----- \\
5.32 \\
-----\end{array}$ & $\begin{array}{c}----1 \\
12.16 \\
--13\end{array}$ & $\begin{array}{l}24.98 \\
------ \\
5.04\end{array}$ & $\begin{array}{l}34.7 \\
7.37 \\
------ \\
------\end{array}$ \\
\hline $\begin{array}{l}\text { Flash point, } K\left({ }^{\circ} \mathrm{F}\right) \\
\text { Pour point, } K\left({ }^{\circ} \mathrm{F}\right)\end{array}$ & $\begin{aligned} 516 & (470) \\
<200 & (<-100)\end{aligned}$ & $\begin{array}{ll}539 & (510) \\
220 & (-64)\end{array}$ & $\begin{array}{ll}539 & (510) \\
213 & (-76)\end{array}$ & $\begin{array}{c}489(420) \\
-----\end{array}$ & $\begin{array}{ll}482 & (407) \\
216 & (-71) \\
\end{array}$ & $\begin{array}{ll}519 & (475) \\
214 & (-75) \\
\end{array}$ \\
\hline $\begin{array}{l}\text { Specific gravity at - } \\
298 \mathrm{~K}\left(77^{\circ} \mathrm{F}\right) \\
289 \mathrm{~K}\left(60^{\circ} \mathrm{F}\right)\end{array}$ & $\begin{array}{r}.998 \\
------ \\
\end{array}$ & -- & & ---- & 0.995 & 0.9465 \\
\hline $\begin{array}{l}\text { Total acid number (tan } \\
\mathrm{Mg} \mathrm{KoH} / \mathrm{g} \text { oil }\end{array}$ & 0.07 & 0. & & 0.15 & 0.40 & 0.06 \\
\hline $\begin{array}{l}\text { Elastohydrodynamic film } \\
\text { thickness, } \\
\text { h } \mu \text { m }(\mu \text { in. }) \\
\Lambda \text { ratio }(\mathrm{h} / \sigma)\end{array}$ & $\begin{array}{c}0.43(17) \\
0.75\end{array}$ & 0.52 & $(20.4)$ & $\begin{array}{c}0.34(13.2) \\
0.58\end{array}$ & $\begin{array}{c}0.50(19.7) \\
0.87\end{array}$ & $\begin{array}{c}0.66(26) \\
1.15\end{array}$ \\
\hline Specification & $\begin{array}{l}\text { - None - } \\
\text { base stock } \\
\text { no additive }\end{array}$ & MIL-I & 23699 & MIL-L-7808J & DOD-L-85734 & DERD -2487 \\
\hline
\end{tabular}

TABLE 5. - SURFACE PITTING (ROLLING-ELEMENT) FATIGUE LIVES

[NASA spur gear test apparatus; material, CVM AISI 9310; gear bulk temperature, $350 \mathrm{~K}$ ( $170{ }^{\circ}{ }_{\mathrm{F}}$ ); maximum hertz stress, $1 \mathrm{GPa}$ (248 $000 \mathrm{psi}) ;$ speed, $10000 \mathrm{rpm}$.)

\begin{tabular}{|c|c|c|c|c|c|c|c|}
\hline \multicolumn{2}{|c|}{ Lubricant code } & \multirow[t]{2}{*}{$\begin{array}{l}\text { Lubricant } \\
\text { basestock }\end{array}$} & \multicolumn{2}{|c|}{$\begin{array}{l}\text { Gear system life, } \\
\text { millions of stress cycles }\end{array}$} & \multirow[t]{2}{*}{$\begin{array}{l}\text { Weibull } \\
\text { slope }\end{array}$} & \multirow[t]{2}{*}{$\begin{array}{l}\text { Failure } \\
\text { index }^{3}\end{array}$} & \multirow{2}{*}{$\begin{array}{c}\text { Confidence } \\
\text { number, } \\
\text { percent }\end{array}$} \\
\hline NASA & & & 10 percent & 50 percent & & & \\
\hline A & $\mathrm{PE}-5-\mathrm{L} 1274$ & Polyol-ester & 5.1 & 20.4 & 1.36 & 30 out of 30 & -- \\
\hline B & $\begin{array}{c}\mathrm{PE}-5-\mathrm{L} 1307 \\
\text { and } \\
\mathrm{PE}-5-\mathrm{L} 1553\end{array}$ & Polyol-ester & 12.1 & 76 & 1.02 & 20 out of 20 & 84 \\
\hline C & $\mathrm{PE}-3-\mathrm{L} 1316$ & Polyol-ester & 5.67 & 20.7 & 1.46 & 20 out of 20 & 55 \\
\hline D & $\mathrm{PE}-5-\mathrm{L} 1304$ & Polyol-ester & 11.75 & 50.8 & 1.29 & 17 out of 20 & 83 \\
\hline $\mathrm{E}$ & $P E-7.5-L 1310$ & Polyol-ester & 46.5 & 152 & 1.59 & 15 out of 19 & 99 \\
\hline
\end{tabular}

${ }^{a}$ Number of failures out of number of tests.

bercent of time that 10 percent life obtained with - each lubricant will have the same relation to the 10 percent life of lubricant NASA $A$. 

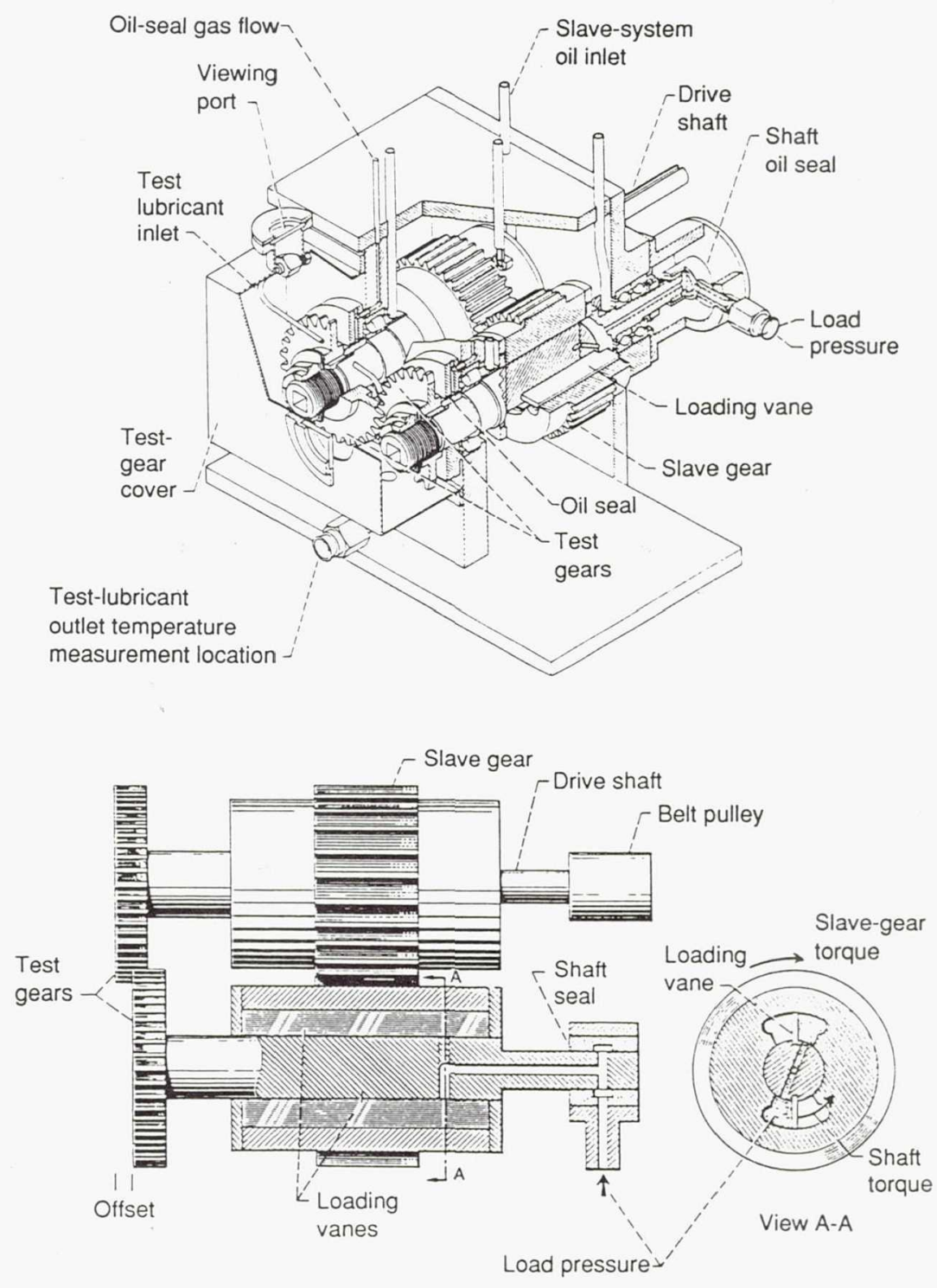

Figure 1.- NASA Lewis Research Center's gear fatigue test apparatus.

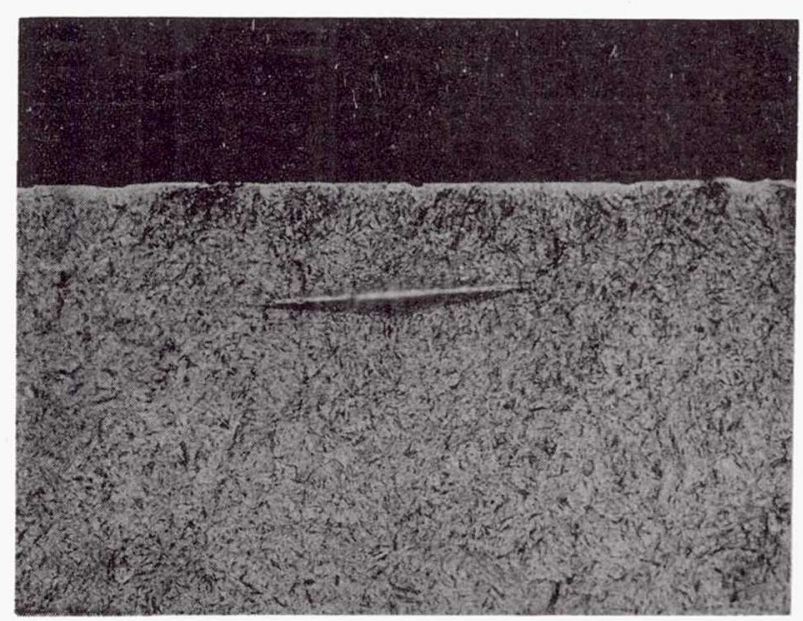

(a) Case

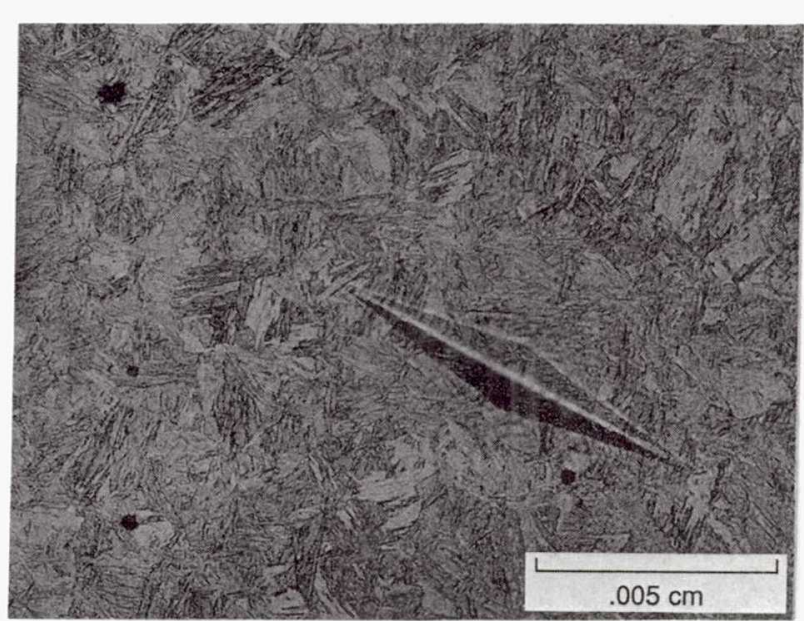

(b) Core.

Figure 2.- Photomicrographs of case and core of CVM AISI 9310 spur gears. 


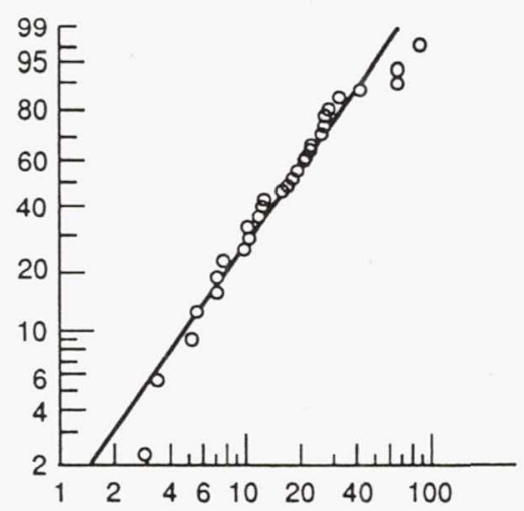

(a) Lubricant A.

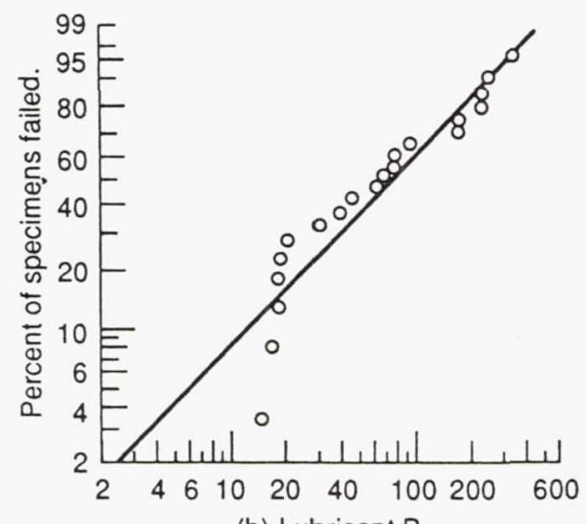

(b) Lubricant B.

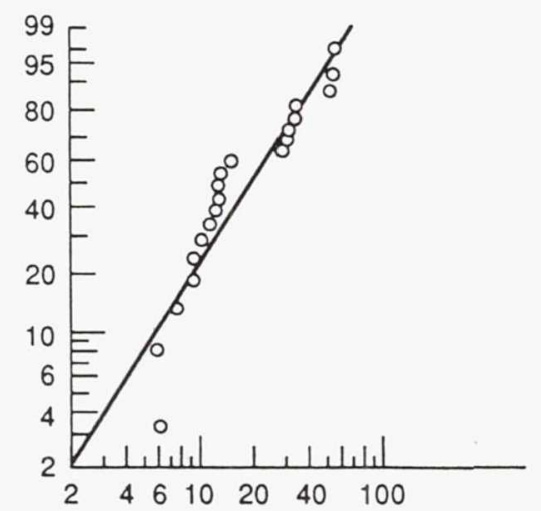

(c) Lubricant $\mathrm{C}$.

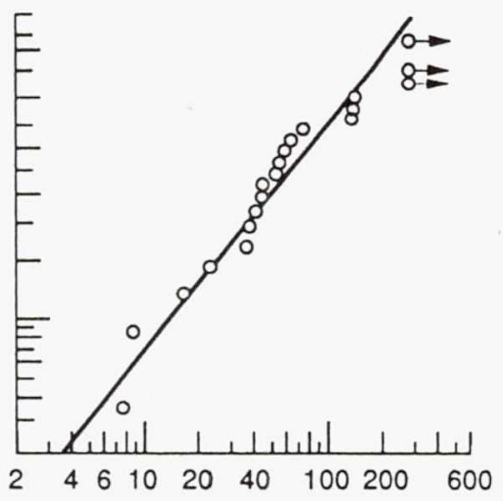

(d) Lubricant $\mathrm{D}$.

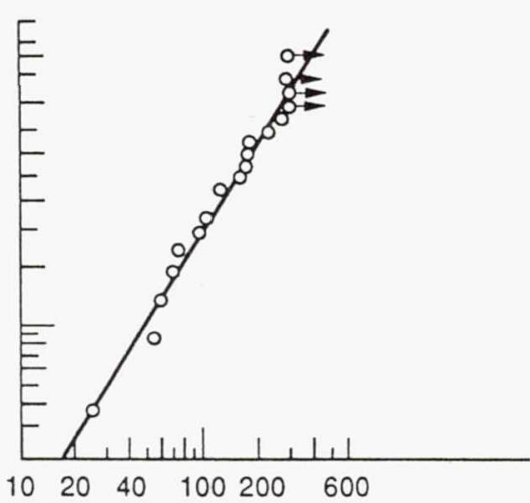

(e) Lubricant E.

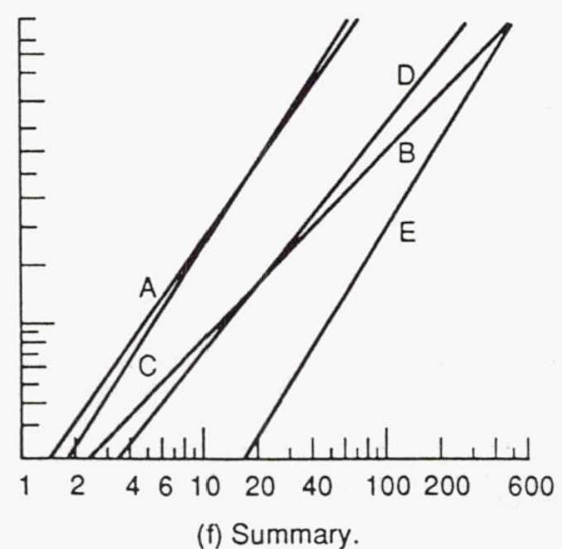

(f) Summary.

Specimen life, millions of stress cycles.

Figure 3.-Surface pitting fatigue lives of AISI 9310 spur gears run with five different lubricants. Pitch diameter $8.39 \mathrm{~cm}$ (3.5 in); speed 10000 RPM; maximum Hertz stress $1.71 \mathrm{GPa}$ (248 ksi); gear temperature $350 \mathrm{~K}\left(170^{\circ} \mathrm{F}\right)$. 


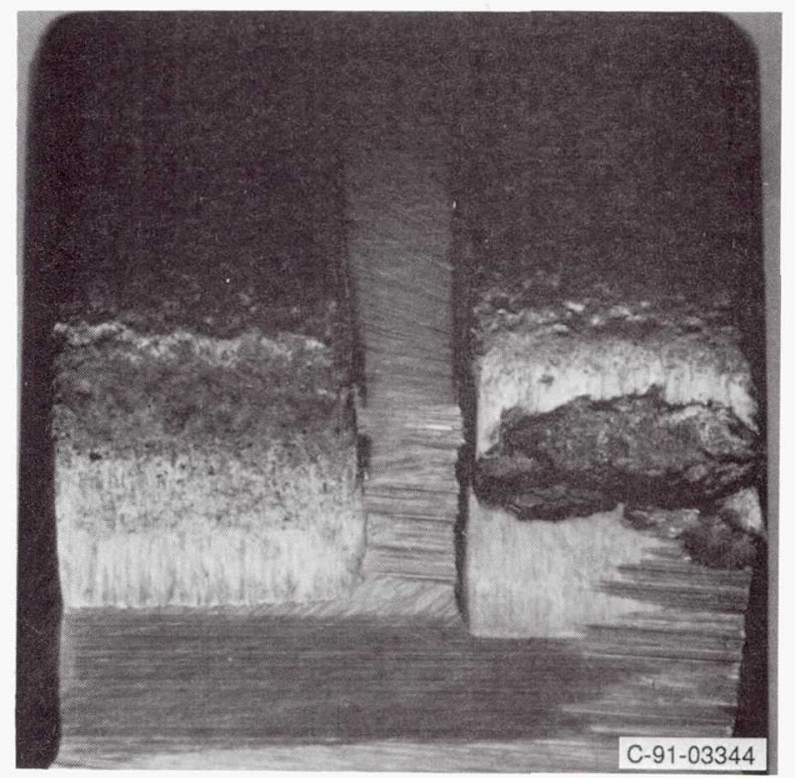

(a) Typical fatigue spall.

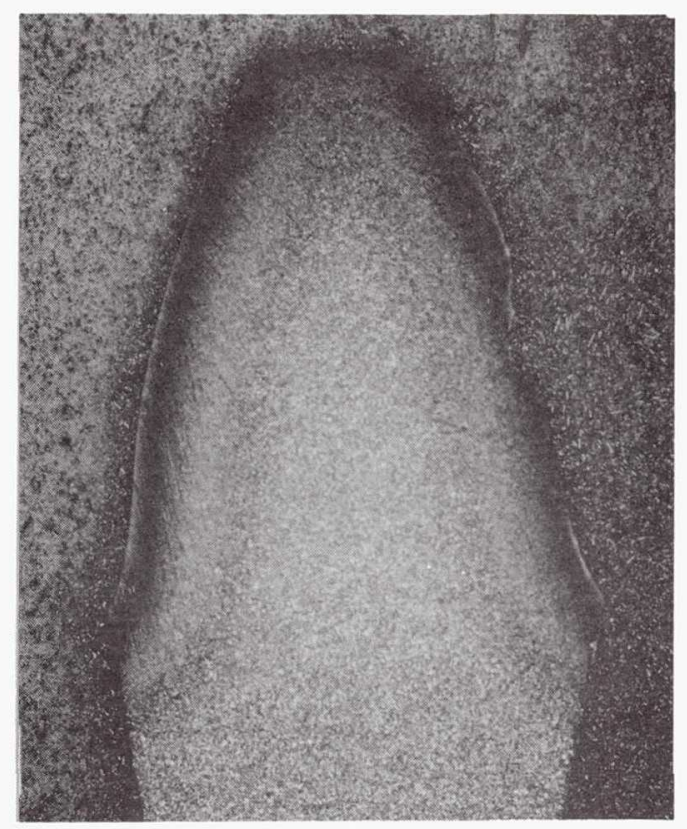

(b) Cross section of typical fatigue spall.

Figure 4.- Fatigue spall for lubricant A.

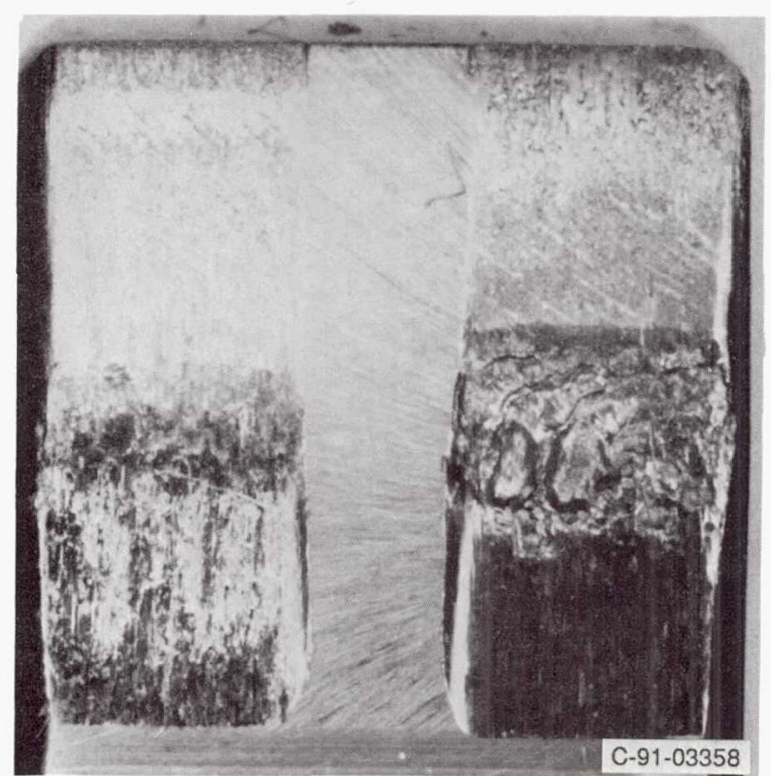

(a) Typical fatigue spall.

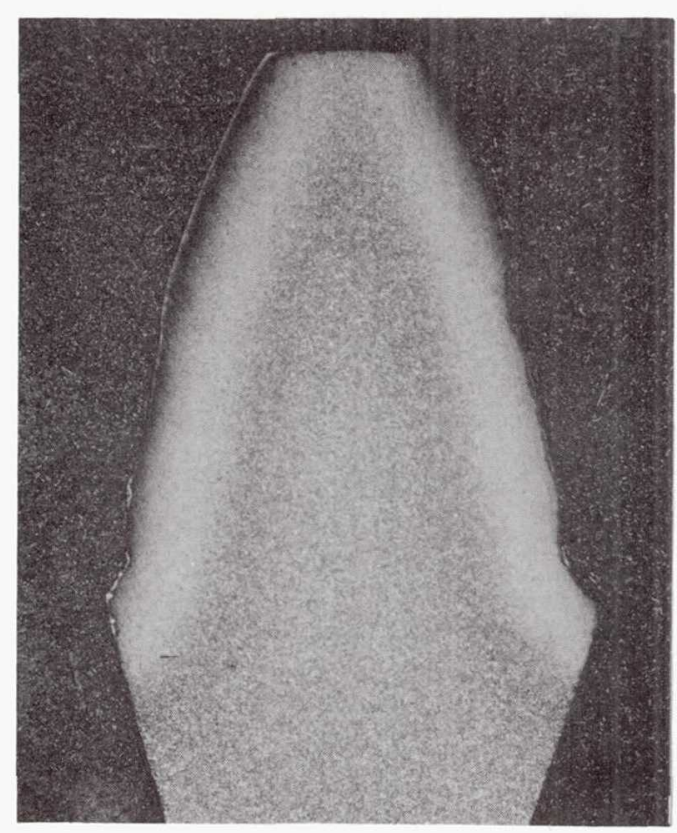

(b) Cross section of typical fatigue spall.

Figure 5.-Fatigue spall for lubricant B. 


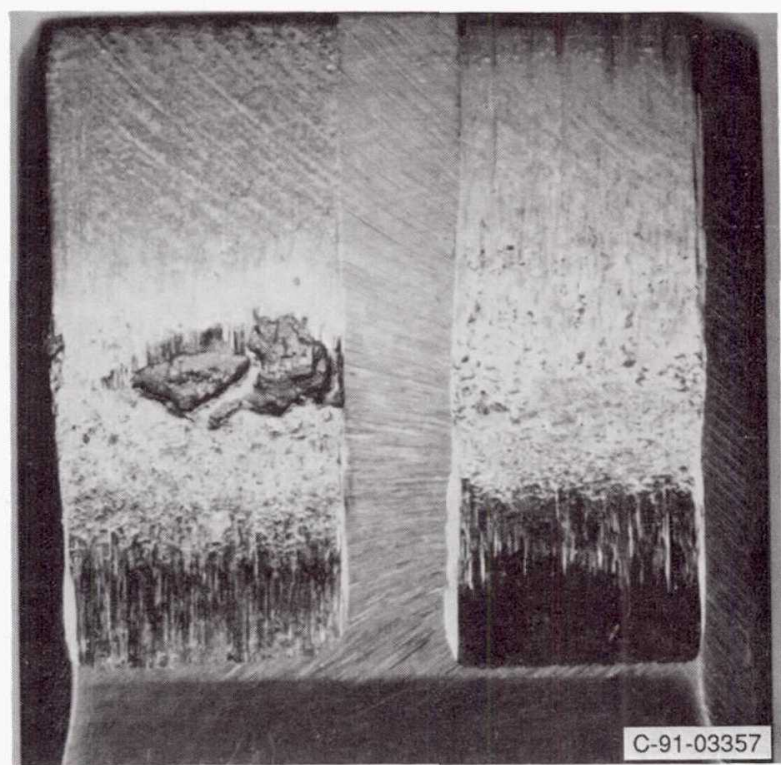

(a) Typical fatigue spall.

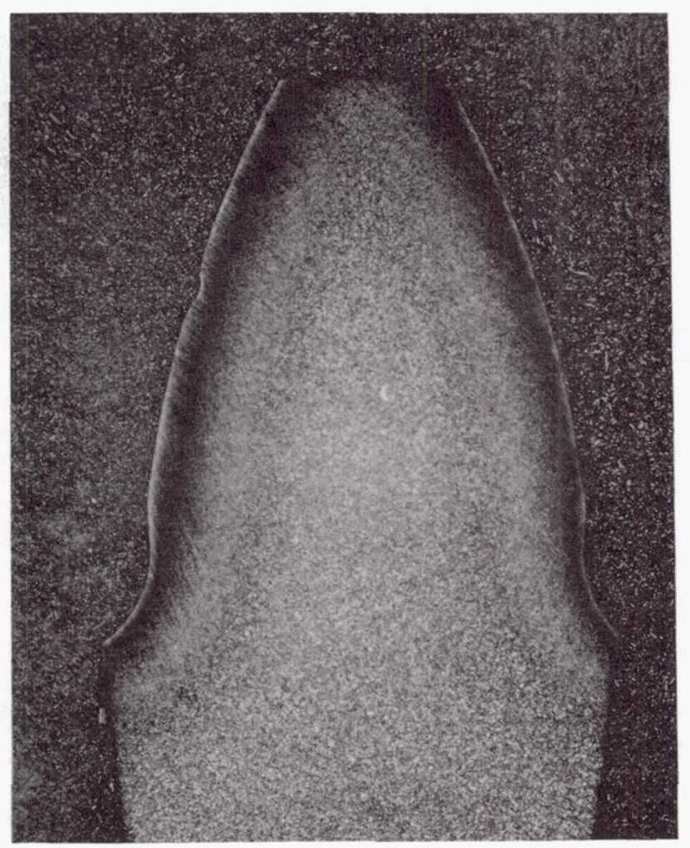

(b) Cross section of typical fatigue spall.

Figure 6.- Fatigue spall for lubricant $C$

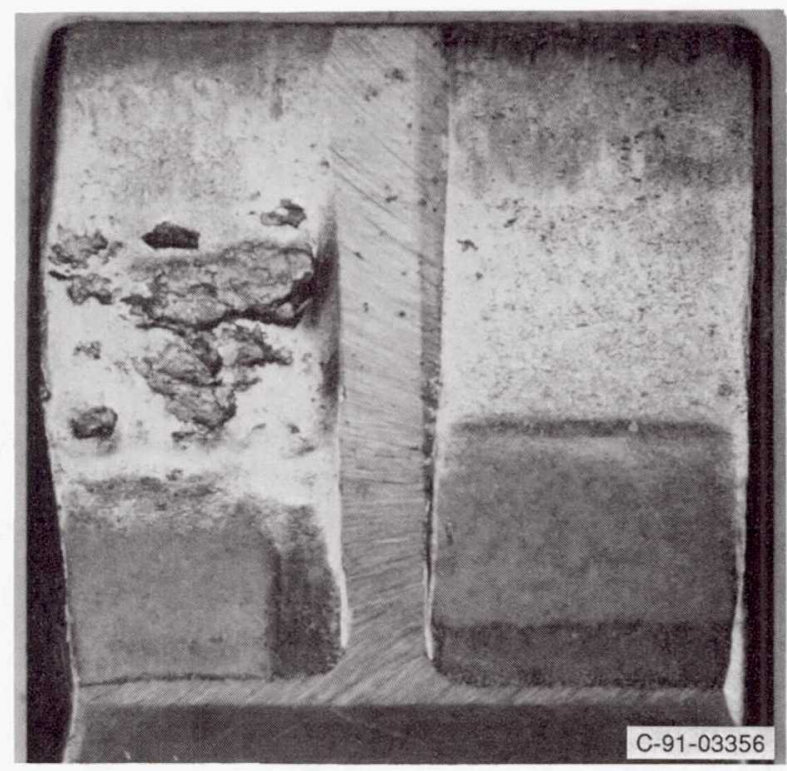

(a) Typical fatigue spall.

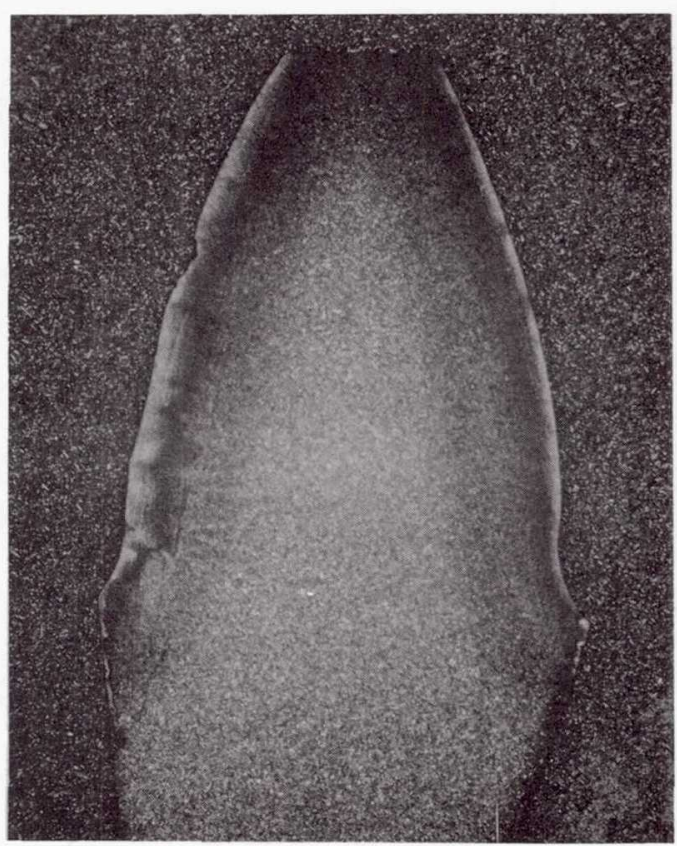

(b) Cross section of typical fatigue spall.

Figure 7.-Fatigue spall for lubricant D. 


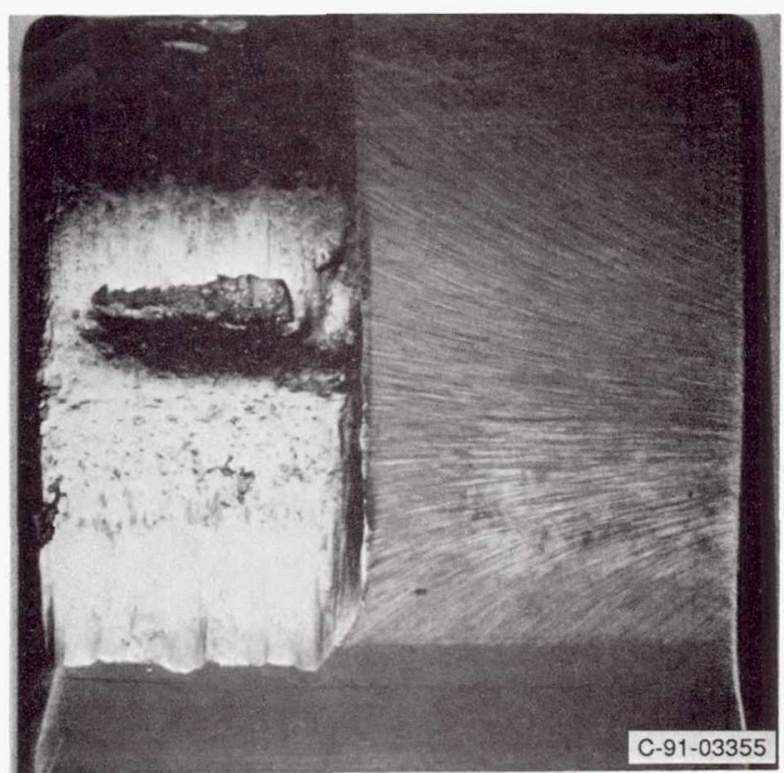

(a) Typical fatigue spall.

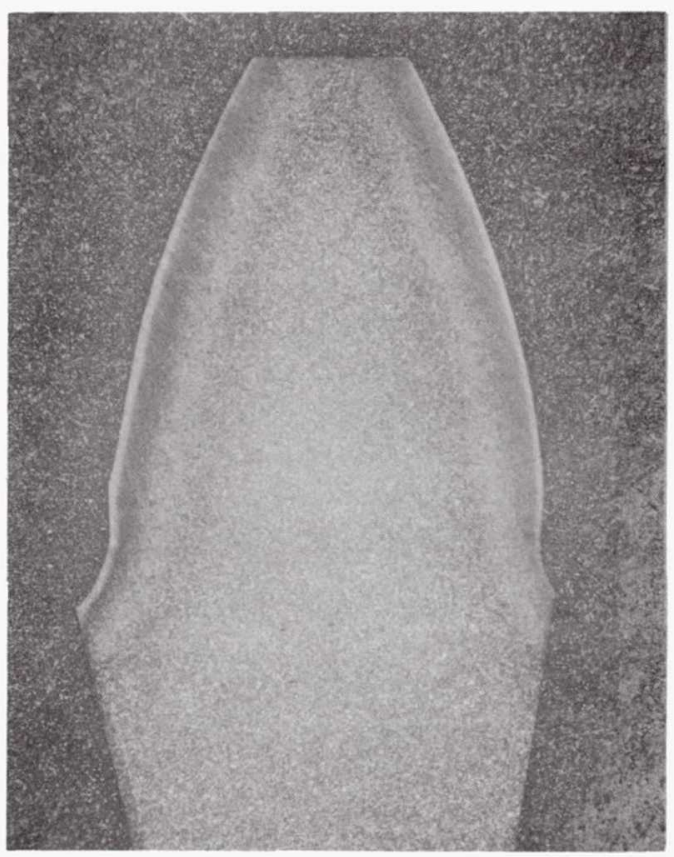

(b) Cross section of typical fatigue spall.

Figure 8.-Fatigue spall for lubricant $E$. 


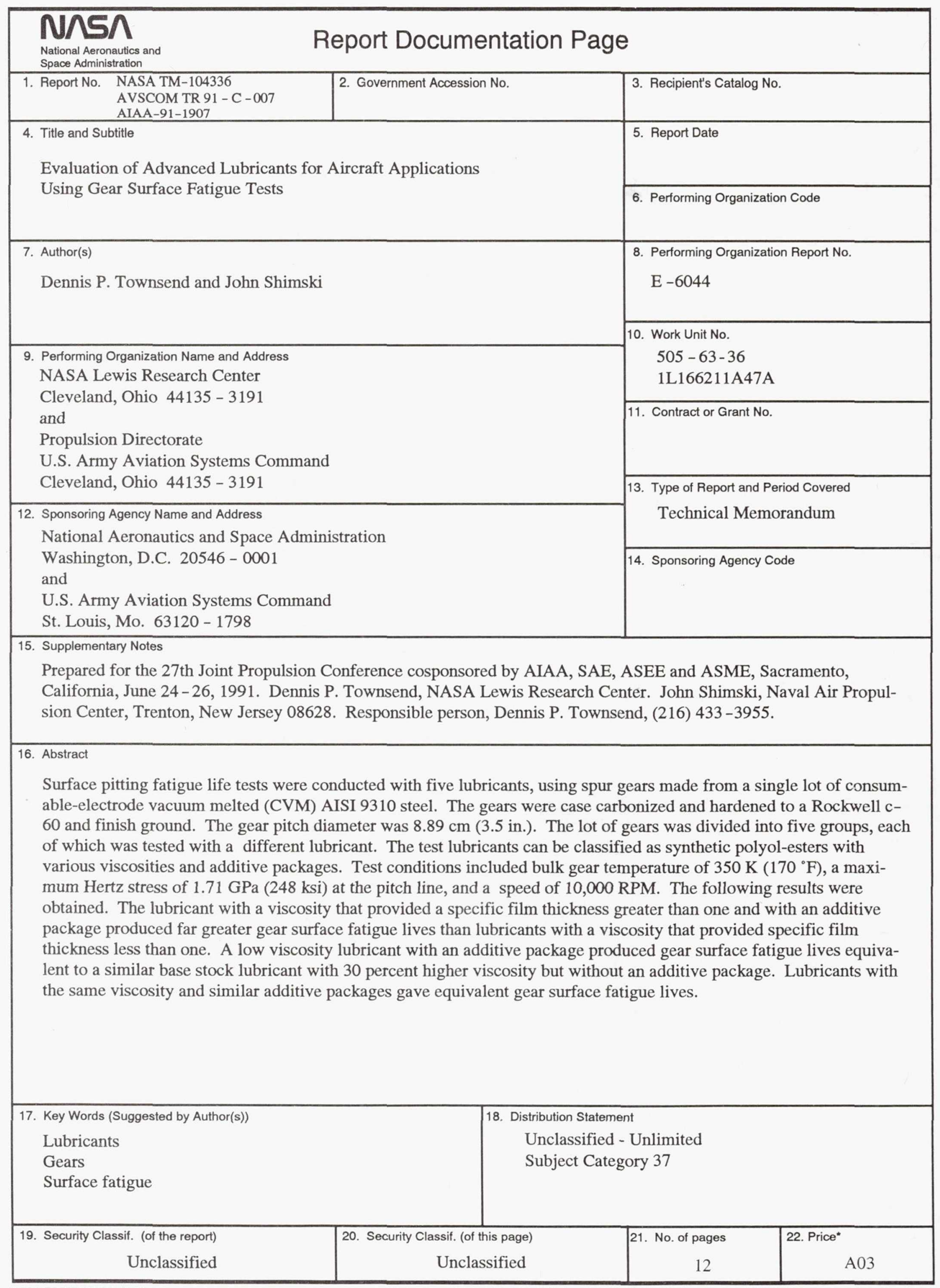

